\title{
To avoid or not to avoid, that's the question
}

Citation for published version (APA):

van Vliet, C. (2021). To avoid or not to avoid, that's the question: the relationship between pain-related avoidance behaviour, pain-related fear, and pain reports. [Doctoral Thesis, Maastricht University, KU Leuven]. Boekenplan. https://doi.org/10.26481/dis.20210111cv

Document status and date:

Published: 01/01/2021

DOI:

$10.26481 /$ dis.20210111cv

Document Version:

Publisher's PDF, also known as Version of record

\section{Please check the document version of this publication:}

- A submitted manuscript is the version of the article upon submission and before peer-review. There can be important differences between the submitted version and the official published version of record.

People interested in the research are advised to contact the author for the final version of the publication, or visit the DOI to the publisher's website.

- The final author version and the galley proof are versions of the publication after peer review.

- The final published version features the final layout of the paper including the volume, issue and page numbers.

Link to publication

\footnotetext{
General rights rights.

- You may freely distribute the URL identifying the publication in the public portal. please follow below link for the End User Agreement:

www.umlib.nl/taverne-license

Take down policy

If you believe that this document breaches copyright please contact us at:

repository@maastrichtuniversity.nl

providing details and we will investigate your claim.
}

Copyright and moral rights for the publications made accessible in the public portal are retained by the authors and/or other copyright owners and it is a condition of accessing publications that users recognise and abide by the legal requirements associated with these

- Users may download and print one copy of any publication from the public portal for the purpose of private study or research.

- You may not further distribute the material or use it for any profit-making activity or commercial gain

If the publication is distributed under the terms of Article $25 \mathrm{fa}$ of the Dutch Copyright Act, indicated by the "Taverne" license above, 
Summary 


\section{To avoid or not to avoid, that's the question}

Why is it that some people develop chronic pain after an injury, while others don't? Pain has a clear function for our survival, because it signals potential harm or danger to the body and it promotes behaviours, such as avoidance and escape, to protect ourselves against these dangers. However, pain could also become a false alarm, especially in the case of chronic pain, where there is often no objectifiable injury and where pain is disconnected from its original function.

Avoidance is considered key in the development and maintenance of chronic pain. Fear-avoidance models propose that pain-related fear may spur avoidance behaviour leading to chronic pain disability. So far, the fear-avoidance model assumes a unidirectional relationship between pain-related fear and avoidance, i.e. pain-related fear evokes avoidance behaviour. However, little is known about how avoidance behaviour subsequently affects pain-related fear and pain. In this $\mathrm{PhD}$ research project we introduced a new line of experimental work to further investigate the relationship between pain-related avoidance behaviour and pain-related fear. In a series of studies we have experimentally manipulated (the perception of) avoidance behaviour and tested its effects on changes in fear and pain reports. The results of our studies indicated that engaging in avoidance may (paradoxically) increase rather than decrease pain-related fear (i.e. bidirectionality hypothesis, whereby pain-related fear leads to avoidance behaviour (one direction) and in turn, engaging in avoidance behaviour increases painrelated fear (other direction)).

In our first study (see chapter 2) we tested the effects of avoidance of a painful heat stimulus on pain-related fear and pain. The results showed that self-reported pain-related fear was higher after performing an avoidance response (pressing the stop-button), despite equal intensities and duration of the heat stimulus as in the control condition. In our second study (see chapter 3), where we also tested the effects of avoidance of a painful heat stimulus, we replicated the findings of the first study, whereby we observed higher pain-related fear levels when the avoidance response was no longer available compared to those when the avoidance response was available. We also found that perceived avoidance attenuates pain reports despite exposure to identical stimulus intensity. In addition, the results showed that increased threat appraisals mediated the 
relationship between avoidance behaviour and increased pain-related fear. Together, these results provide support for a bidirectional relationship between fear and avoidance.

Chapter 4 describes our third experimental study, where we examined motorbehavioural characteristics of avoidance behaviours during different movements, using the HapticMaster, a 3-degrees of freedom, force-controlled robotic arm. We investigated the changes in pain-related fear and pain when avoidance behaviour was no longer effective. The results indicated participants became more afraid of and sensitive to pain, when previously acquired avoidance behaviour was no longer effective. Also, participants continued to show avoidance behaviour despite it being not adaptive anymore. These findings suggest that ineffective avoidance may play a role in the development and maintenance of chronic pain.

In our fourth experimental study (see chapter 5), where we also applied a robotic armreaching task, we investigated whether performing a movement to avoid a painful stimulus in the context of a novel, ambiguous movement increased threat and painrelated fear towards this movement, and whether avoidance behaviour persisted when given the choice between performing the acquired movement to avoid a painful stimulus or an alternative, novel movement. The results revealed that acquired avoidance behaviour in the presence of a novel, ambiguous movement elevated pain expectancy and pain-related fear towards that novel movement, even in the absence of confirmation of the actual threat level of the novel movement. We also observed persisting avoidance behaviour towards the novel movement, thereby preventing disconfirmation of the novel movement threat appraisals. These findings suggest that avoidance in the context of other neutral activities/movements may lead to the development and maintenance of threat appraisals and irrational fears.

Taken together, the findings reported in this dissertation provide support for the bidirectional relationship between pain-related fear and avoidance and constitute an important step in furthering our understanding of the underlying mechanisms in the development and maintenance of chronic pain. 



\title{
Samenvatting
}

\author{
(Dutch summary)
}




\section{Vermijden of niet vermijden, dat is de vraag}

Waarom ontwikkelen sommige mensen chronische pijn na een letsel, terwijl dat bij anderen niet gebeurt? Pijn heeft een duidelijke functie voor ons overleven, omdat pijn potentiële schade of gevaar voor het lichaam signaleert en het bevordert gedragingen, zoals vermijden en ontsnappen, om onszelf te beschermen tegen deze gevaren. Echter, pijn kan ook een vals alarm worden, vooral in het geval van chronische pijn, waar er vaak geen sprake is van een daadwerkelijk letsel en waar pijn niet meer verbonden is met zijn originele functie.

Vermijding wordt beschouwd als zijnde cruciaal in de ontwikkeling en het behoud van chronische pijn. Vreesvermijdingsmodellen gaan ervan uit dat pijngerelateerde vrees vermijdingsgedrag kan aansporen, hetgeen kan leiden tot functiebeperkingen als gevolg van chronische pijn. Tot dusverre veronderstelt het vreesvermijdingsmodel een unidirectionele relatie tussen pijngerelateerde vrees en vermijding, i.e. pijngerelateerde vrees roept op tot vermijdingsgedrag. Echter, er is weinig bekend hoe vermijdingsgedrag vervolgens pijngerelateerde vrees en pijn beïnvloedt. In dit doctoraatsproject introduceerden we een nieuwe reeks van experimenteel onderzoek om de relatie tussen pijngerelateerd vermijdingsgedrag en pijngerelateerde vrees verder te onderzoeken. In een aantal studies hebben we (de perceptie van) vermijdingsgedrag experimenteel gemanipuleerd en de effecten ervan op veranderingen in vrees en pijn getest. De resultaten van onze studies gaven aan dat het uitoefenen van vermijdingsgedrag (paradoxaal) kan leiden tot een toename, in plaats van een afname van pijngerelateerde vrees (i.e. bidirectionaliteitshypothese, waarbij pijngerelateerde vrees leidt tot vermijdingsgedrag (de ene richting) en, op zijn beurt, het uitoefenen van vermijdingsgedrag leidt tot een toename van pijngerelateerde vrees (de andere richting)).

In onze eerste studie (zie hoofdstuk 2) testten we de effecten van vermijding van een pijnlijke warmteprikkel op pijngerelateerde vrees en pijn. De resultaten toonden aan dat zelf-gerapporteerde pijngerelateerde vrees hoger was na het uitvoeren van een vermijdingsreactie (het indrukken van een stopknop), ondanks het feit dat intensiteit en duur van de warmteprikkel in werkelijkheid gelijk waren als in de controle conditie. In onze tweede studie (zie hoofdstuk 3), die ook betrekking had op het vermijden van een warmteprikkel, repliceerden we de bevindingen van onze eerste studie, waarbij we 
hogere pijngerelateerde vrees observeerden op het moment dat de vermijdingsreactie niet langer beschikbaar was ten opzichte van de pijngerelateerde vrees toen de vermijdingsreactie nog wel beschikbaar was. We vonden ook dat perceptuele vermijding leidt tot een gerapporteerde lagere pijn, ondanks het feit dat er sprake was van blootstelling aan een identieke intensiteit van de warmteprikkel. Bovendien bleek uit de resultaten dat de relatie tussen vermijdingsgedrag en toegenomen pijngerelateerde vrees werd gemedieerd door een toegenomen dreigingsevaluatie. Tezamen leveren deze resultaten ondersteuning voor een bidirectionele relatie tussen vrees en vermijding.

Hoofdstuk 4 beschrijft onze derde experimentele studie, waar we de motorische vermijdingskarakteristieken onderzochten van verschillende bewegingen, gebruik makend van de HapticMaster, een over 3-vrijheidsgraden beschikkende, krachtgeregelde robotarm. We onderzochten de veranderingen in pijngerelateerde vrees en pijn wanneer het vermijdingsgedrag niet langer effectief was. De resultaten gaven aan dat deelnemers banger van en gevoeliger voor pijn werden, wanneer het eerder aangeleerde vermijdingsgedrag niet langer effectief was. Deelnemers bleven ook het vermijdingsgedrag vertonen ondanks dat het niet meer adaptief was. Deze bevindingen suggereren dat ineffectieve vermijding mogelijk een rol speelt in de ontwikkeling en het behoud van chronische pijn.

In onze vierde experimentele studie (zie hoofdstuk 5), waarin we ook gebruik maakten van de robotarm bewegingstaak, onderzochten we of het uitvoeren van een beweging om een pijnlijke stimulus te vermijden in de context van een nieuwe, ambigue beweging dreiging en pijngerelateerde vrees verhoogde ten aanzien van deze nieuwe beweging, en of het vermijdingsgedrag aanhield wanneer de keuze werd gegeven tussen het uitvoeren van de aangeleerde beweging om een pijnlijke stimulus te vermijden of een alternatieve, nieuwe beweging. De resultaten maakten duidelijk dat aangeleerd vermijdingsgedrag in de anwezigheid van een nieuwe, ambigue beweging pijnverwachting en pijngerelateerde vrees verhoogde ten opzichte van deze nieuwe beweging, zelfs in de afwezigheid van de bevestiging van de actuele dreiging van de nieuwe beweging. We zagen ook aanhoudend vermijdingsgedrag voor deze nieuwe beweging, hetgeen ontkenning van de dreigingsevaluatie van de nieuwe beweging voorkwam. Deze bevindingen suggereren dat vermijding in de context van andere 
neutrale activiteiten/bewegingen kan leiden tot de ontwikkeling en het behoud van dreigingsevaluaties en irrationele vrees.

Samenvattend geven de bevindingen die gerapporteerd worden in deze dissertatie ondersteuning voor de bidirectionele relatie tussen pijngerelateerde vrees en vermijding en zij vormen een belangrijke stap in de richting van het verder begrijpen van de onderliggende mechanismen in de ontwikkeling en het behoud van chronische pijn. 